\title{
Legal Consequences Of Mortgage Right Imposition On Uncertified Land (Letter C) In Case The Grantor Is Passed Away
}

\begin{abstract}
Susilowati ${ }^{1}$, Yuniar Pradhana Mukti ${ }^{2}$ and Gunarto ${ }^{3}$
Abstract. The purpose of this study is to know the implementation of the uncertified land as mortgage right (Letter $\mathrm{C}$ ) and how the effect occurs in case that the grantor is passed away. This research was done with normative juridical approach. Technique of collecting legal material used literature study, while technique of data analysis was done with descriptive qualitative. The author found that UUHT provides an opportunity for owners of uncertified land rights to pledge their land rights in mortgage rights. It is mentioned in Article 10 Paragraph (2) of UUHT stating that if the object of mortgage rights in the form of land rights arising from the conversion of old rights that have been eligible to be registered but the registration has not been done, the granting of the mortgage shall be conducted simultaneously with the application of the right to (Letter C). On the other hand, the mortgagee has died and left the heirs, then there are several ways of settlement made by the bank, namely: If the credit has matured, then the credit is covered by credit insurance. If the credit has matured and the credit insurance has expired, it will be billed up to his heirs by approaching the family by offering loan interest rate relief. It is expected that the government through the National Land Agency can organize the process of land certification in a relatively short time so that it can support the economic activities of the community.

Keywords: Mortgage Right; Uncertified Land; The Grantor Is Passed Away.
\end{abstract}

\section{Introduction}

Debt activities are associated with the terms of the delivery of debt guarantees. This activity is mostly done by individuals and various business entities. Business entities generally strictly require the borrower to submit an item (object) as an object of debt guarantees. The debt guarantee offered (submitted) by the borrower will generally be assessed by the entity before it is accepted as the object of the guarantee on the loan it provides. The assessment that should be done as usual in the field of banking includes judicial judgments and economics. Based on the assessment, it is expected to get good and valuable items as guarantee object. ${ }^{4}$

In practice, matters relating to the grant of guarantee/collateral have been instituted and regulated in full, and the guarantee institution whose object of guarantee is land and objects related to the land is the Mortgage Rights.

Basically, the imposition of mortgages must be done solely by the grantor of the mortgage. Only when absolutely necessary, ie in case the mortgage giver cannot be present before the Notary (PPAT), he is required the use of Power Of Attorney too

\footnotetext{
1 Students of Master of Notarial Law, Faculty of Law, Universitas Islam Sultan Agung email susilowati@gmail.com

2 Students of Master of Law, Faculty of Law, Universitas Islam Sultan Agung email mpradhana@gmail.com

${ }^{3}$ Profesor of Faculty of Law UNISSULA

4 M. Bahsan 2007 Hukum Jaminan dan Jaminan Kredit Perbankan Indonesia Raja Grafindo Persada Jakarta p. 2
} 
Establish Mortgage Right (SKMHT). Accordingly, the power of attorney must be given directly by the mortgagee and must meet the requirements of the cargo as determined. The non-fulfillment of such requirement resulted in the relevant power of attorney being null and void, which means that the power of attorney concerned cannot be used as the basis for the making of APHT (Mortgage Right Agreement). ${ }^{5}$

Under certain conditions, it is needed to make the Power Of Attorney too Establish Mortgage Right to Charge the Mortgage Rights (SKMHT) from the grantor to the receiver (holder) of the mortgage. There are several reasons for making the Power Of Attorney too Establish Mortgage Right (SKMHT) such as:

- Object of the Mortgage Right (land) is outside the working area of Notary which doubles as PPAT.

- Object of Mortgage Rights (land) is not yet certified.

- Object of the Mortgage Rights (land) has not been on the name of the mortgagee.

The period of validity of SKMHT is limited in accordance with the condition of the mortgage object (land). It is in accordance with the rules specified in the Mortgage Law and Regulation of the Minister of Agrarian Affairs/Head of the National Land Agency Number 4 of 1996 concerning the time limit of the use of a power of attorney to impose mortgages certain credits. So that it is possible that the grantor will be passed away before the imposition of mortgage rights. What are the consequences of the law and how it proceeds if SKMHT on land made by the power of attorney who then dies? It needs to be studied and investigated further, as SKMHT is an agreement authorizing the imposition of mortgage rights land.

The provisions regarding the validity limit of SKMHT are intended to prevent the protracted timing of the exercise of that power. This provision does not rule out the possibility of new SKMHT. ${ }^{6}$

Currently, there are many lands that only have Letter C (letter from the village). Letter $\mathrm{C}$ is obtained from the village office where the land is located, Letter $\mathrm{C}$ is a proof of a note in the Village Office. Regarding the Letter $C$ of the village, many people still do not understand what is meant by the Letter $C$ of the village book. Since in the literature or legislation on land matters, it is very rarely discussed or put forward. Regarding the Letter $C$ book of this village, it is actually only used as the basis as a record of tax withdrawals. The description of the land contained in the Letter $\mathrm{C}$ book of the Village is very incomplete and the way of recording is not carefully. So that there will be many problems that arise later because of the lack of accurate data in the book Letter $C$ the village. In addition, the author was interested to know more about the power of excerpts of the Letter $\mathrm{C}$ book of the Village in obtaining land rights acquisition procedures.

Based on the above description, the researcher needs to do research that will be poured with titled "Legal Consequences of Mortgage Right Imposition on Uncertified Land (Letter C) in Case that the Grantor Passed Away"

The formulation of the problem in this research is how is the implementation of of the mortgage right imposition on uncertified land (Letter $\mathrm{C}$ ), and how does the law impose the mortgage right on uncertified land (Letter $\mathrm{C}$ ) if the power of attorney dies?

\footnotetext{
${ }^{5}$ Purwahid Patrik \& Kashadi 2008 Hukum Jaminan Fakultas Hukum Universitas Diponegoro Semarang p.73.

${ }^{6}$ Ibid. p. 75.
} 


\section{Research Methods}

Approach method used in this research was method of juridical normative approach. It is legal research done by studying materials derived fromvarious legislation and other material from various literatures. ${ }^{7}$

Data sources used in this study included the primary legal materials, namely Act No. 5 of 1960 on the Basic Regulations of the Agrarian Principles and the legal provisions of a technical nature of the mortgage right namely Act No. 4 of 1996 on the Mortgage Rights Land and things related land, Act No.24 Of 1997 on Land Registration, Act No.2 Of 2014 About Amendment to Act No.30 Of 2004 Concerning Position of Notary, Government Regulation Number 37 Of 1998 on Official Regulation of Officials of Land Agreement Authority. Secondary data sources were materials that are closely related to primary legal materials and can help analyzing and understanding the legal materials. The secondary data were: in the form of literature, scientific papers, research results, workshops related to research materials and legal materials research is a legal dictionary.

The technique of collecting legal material in this research was done by literature study technique (study document). The analysis technique used in this research was qualitative descriptive.

\section{Discussion}

\subsection{Implementation of Imposition of Mortgage Right on Uncertified Land (Letter C)}

The implementation of the imposition of Mortgage Rights is carried out through two stages of activity, namely the stage of Granting of Mortgage Right, which is performed before the Land Agreement Official (PPAT) and the second stage is the Registration of Mortgage Rights, carried out at the Land Affairs office. The Grant of Mortgage Right stage begins with a promise to grant the Mortgage Right as a guarantee of certain debt repayment. The pledge to grant the Mortgage Right is poured in and is an integral part of the debt agreement of the related receivable or any other agreements that incur such debt.

This stage can be deduced from the provision in Article 10 paragraph (1) UUHT (Law on Mortgage Right) stating that the provision of Mortgage Right is preceded by a promise to grant the Mortgage Right as a certain debt repayment guarantee, which is poured in and is an inseparable part of the related debt agreement or other agreement which incurring such debt.

From the provisions of Article 10 paragraph (1) of the UUHT, it is known that the granting of Mortgage Rights must be agreed upon first and the required promise shall be poured in and constitute an inseparable part of the debt agreement of the related receivable or any other agreement which incurred such debt. This means any pledge to grant Mortgage Rights is first set forth in the debt agreement.

\footnotetext{
${ }^{7}$ Soerjono Soekanto dan Sri Mamudji 2007 Penelitian Hukum Normatif (Suatu Tinjauan Singkat) Raja Grafindo Persada Jakarta p.13.
} 
UUHT provides an opportunity for owners of uncertified land to pledge their land rights with Mortgage Right. It is mentioned in Article 10 Paragraph (2) of UUHT stating that if the object of mortgage rights in the form of land rights arising from the conversion of old rights that have been eligible to be registered but the registration has not been done. The granting of the mortgage shall be conducted simultaneously with the application of the right to the land concerned. Although in legislation, it is possible to impose mortgages on land that have not yet been certified, but in general, the owners of land have difficulties because in general the creditor wants the land already certified. It is caused there is already strong evidence of ownership of the land right. It makes obstacles for the owner of uncertified land (Letter $\mathrm{C}$ ), if want to obtain funds from other parties creditors.

In article 10 of Act No. 4 of 1996, it may be possible to impose a mortgage on the land that has not been certified (Letter $\mathrm{C}$ ). However, at the time of imposition of the mortgage, it must be done at the same time registration of rights to the land. Article 10 paragraph (3) of Act No. 4 Of 1996 states:

If the object of mortgage rights in the form of rights to land arising from the conversion of old rights that have been eligible for registration but the registration has not been made, the granting of the mortgage is done simultaneously with the registration of the land title concerned.

The article is an exception to the principle that the object of Mortgage Right is land according to UUPA registered and transferable because in that provision it is possible to have a Mortgage right on the land derived from the conversion of the old right. It is already eligible for registration, but not yet registered, so according to UUPA it is not Land Right. Since the right to land of the former Western country, since September 24, 1980 has ceased to exist (Presidential Decree No. 32 Of 1979 jo PMDN No. 3 Of 1979), "land originating from the conversion of old rights is customary land rights.

Elucidation of article 10 of Act No. 4 of 1996 (UUHT) states that the possibility of granting property rights to customary land title is intended to:

- Provide an opportunity to holders of uncertified land to obtain credit.

- Encourage the certification of land rights in general.

This article makes it easy for the economically weak groups that need credit, and the only guarantee that is owned is a piece of land that has not been certified (Letter C).

Guarantee is a crucial factor in lending process in the bank. One of the most frequently used collateral is the Mortgage Right.

In practice, the imposition of collateral for land that has not been certified (Letter C) is preceded by the creation Power Of Attorney too Establish Mortgage Right (SKMHT). By a notary/PPAT partner of the Bank, which then proceed with the making of APHT. In this case, according to the researcher, it is not appropriate because SKMHT is actually not for uncertified land as the guarantee of mortgage right. However, SKMHT is made in condition that the grantor cannot present in the Granting of Mortgage Right. In principle, the provision of a Mortgage Right shall be made by the grantor. This is in accordance with the general principle which states that, in principle, legal action must be carried out by the interested parties themselves. However, such provisions may be 
disregarded and the person or legal entity may authorize his actions to another person or party. ${ }^{8}$

The exceptions to the above principle are clearly stipulated in the Elucidation of Article 15 paragraph (1) of the UUHT, which states "only when it is absolutely necessary that a person may use Power Of Attorney too Establish Mortgage Right (SKMHT). So, SKMHT is only allowed under special circumstances, ie if the grantor of Mortgage right cannot present himself in front of PPAT. In this case the Grantor of Liabilities must appoint the other party as its proxy in the making of SKMHT which is made by authentic Agreement and its manufacture is submitted by Notary or PPAT (Land Agreement Official). ${ }^{9}$

In practice, prior to the certificate of land rights, APHT cannot be made, even if the period of SKMHT is end. In such case, new SKMHT is made. After the rights certificate has been published, it is followed by the making of APHT. Such matter is not in accordance with those specified in Article 10 paragraph (3) of UUHT mentioning that:

If the object of Mortgage right consists of rights to land derived from the conversion of old rights that have been eligible for registration but the registration has not been made, the granting of the Mortgage Right shall be conducted simultaneously with the registration of the land title concerned.

From the provision of Article 10 Paragraph (3) UUHT, it is seen that for the imposition of mortgages on uncertified land rights, the granting of mortgages shall be conducted simultaneously with the application of registration of the land rights concerned. Thus, it should be at the time of making APHT by PPAT as well as registration of land rights. Therefore, there is no need to wait for the issuing of land titles certificate. Certificate of land rights as evidence of the authority of the Insurer to carry out legal actions against the land which is the object of the Mortgage Right, it is required at the time of registration of the Mortgage Right at the Land Office.

The provision of Article 10 paragraph (3) is related to the provision that the Depositary Guarantor must be the person authorized to perform legal acts against the object of Mortgage Rights. This is affirmed in Article 8 paragraph (1) UUHT stating that the Giver of Mortgage is an individual or legal entity that has the authority to perform legal acts against the object of the related Mortgage Rights.

With the enactment of UUHT, the possibility to make customary land rights as collateral is only legal history, because in the elucidation of Article 10 paragraph (3) shows how to increase the granting of collateral to become Mortgage Right. UUHT is not only intended to facilitate the flow of credit, which also supports the mission of banking, but also emphasizes the legal certainty aspect. It is the requirement to be registered and by itself to further encourage land registration activities in Indonesia.

\subsection{Legal Effect on Imposing a Mortgage Right in Uncertified Land (Letter C) if the mortgagee dies}

Land has a minimum letter, it is usually a Letter $\mathrm{C}$. Letter $\mathrm{C}$ is obtained from the village office where the land is located, Letter $\mathrm{C}$ is a proof of a note in the Village Office. In

\footnotetext{
${ }^{8}$ Boedi Harsono 2003 Hukum Agraria Indonesia sejarah Pembentukan Undang-undang Pokok Agraria Isi dan Pelaksanaannya Djambatan Jakarta p. 435

9 Maria S.W. Sumardjono 2001 Kebijakan Pertanahan antara Regulasi dan Implementasi Buku Kompas Jakarta p. 126
} 
the literature or legislation on land, it is very rarely discussed or raised about the Letter $\mathrm{C}$ of the village. Regarding the book of letter $\mathrm{C}$, this is actually only used as the basis for tax withdrawal records. Information on the land contained in the book Letter $\mathrm{C}$ is very incomplete and the way of recording is not satisfied, so that there will be many problems that arise later because of lack of complete accurate data in book letter c.

In accordance with the provisions of Article $18 \mathrm{UUHT}$, the death of the Insured is not one of the reasons for the removal of the Mortgage Right. Similarly, the granting of power to impose mortgages is set forth in the form of an "absolute power". It can be seen from the statement "irrevocable or unfinished by any cause" as provided in Article 15 paragraph (2) of the UUUHT which indicates that SKMHT is a letter of "absolute power". ${ }^{10}$

As for the provisions of Article 15 paragraph (2), the power to impose a mortgage right shall not be withdrawn or may not be terminated by any cause except that the power of attorney has been exercised or due to the expiry of its term as referred to in paragraphs (3) and (4) .

From the above provisions, it can be deduced that:

- The law stipulates that SKMHT is an absolute power of attorney, that is, irrevocable or non-reversible due to any reason whatsoever.

- SKMHT is granted for one time, because SKMHT will only be terminated if "the power to impose the mortgage has been executed"

- The period of validity of SKMHT is limited Since UUHT has determined SKMHT is an absolute power of attorney, so it is no longer need to be agreed or included in SKMHT. However, in the blank it is still found the words, which read "this power cannot be withdrawn and does not end because of any cause, except because it has run out of time."

In facing the problem of the credit has not been settled with the collateral of uncertified land while the debtor has passed away and leave the heir, then there are 3 (three) ways to overcome the issue,

- If credit has matured then credit is covered by a credit insurance.

- If the credit has expired and the credit insurance has expired, it will be billed up to his heirs by approaching kinship and offering loan interest rate relief.

- Ask the heirs concerned to make a sale under the hands of the object of the guarantee.

According to the authors, the bank can still use its rights based on the SKMHT to install APHT if the land certificate has been completed, considering SKMHT according to UUHT is special and can be said is an absolute power, which can not end with the death of the giver of mortgage.

If then the parents who pledged the uncertified land (Letter $\mathrm{C}$ ) died, the guarantee object is still exist and can be executed by the bank if the debtor (child) is default.

Thus, although under the law of inheritance, which owns the land after the parent dies are his heirs, the alteration of the owner does not result in the abolition of the mortgage. The mortgage is still attached to the land. Accordingly, the Power of Attorney to impose the Mortgage Right (SKMHT) is valid until the expiration of the

\footnotetext{
${ }^{10}$ Nur Hayatun Nufus 2010 Proses Pembebanan Hak Tanggungan Terhadap Tanah Yang Belum Bersertipikat (Studi di PT Bank Rakyat Indonesia Tbk Unit Bekasi Kota) Tesis of Diponegoro University Semarang
} 
principal agreement, and may still be in the APHT (the Agreement of Assurance) even if the APHT provider dies.

\section{Conclusion}

The imposition of Mortgage Rights with the object of uncertified land title in UUHT is intended to provide an opportunity to persons who have land rights, should be registered, but have not been registered to obtain credit. In addition, it is also intended to encourage the certification of land rights. In the event that the object of the Mortgage Right is the right to uncertified, according to UUHT, at the time of granting the Mortgage Right with the making of APHT by PPAT also conducted registration of land rights concerned. However, in practice, the registration of land rights was firstly done and waits until the land certificate is issued. The granting of indirect borrowing rights is made by APHT, but SKMHT is made in advance, whereas in the provisions of UUHT, the making of SKMHT is in the case of Giver of Insurers cannot present in the grant of Mortgage, not to give mortgage rights grant to uncertified. Thus the purpose of granting as an opportunity for owners of uncertified land rights to obtain credit as determined by UUHT cannot be realized.

Facing the problem of the credit has not been settled with the collateral of uncertified land (Letter $\mathrm{C}$ ) while the mortgagee has died and leave the heirs, then there are some ways of settlement done by the bank, namely: If the credit has matured, the credit is cover by credit insurance. If the credit has matured and the credit insurance has expired, it will be billed up to his heirs by approaching the family by offering loan interest rate relief. Although under the law of inheritance, which owns the land after the parent's death is his heir, the alteration of the owner does not result in the abolition of the mortgage. The mortgage is still attached to the land. Accordingly, the Power of Attorney to impose the Mortgage Right (SKMHT) is valid until the expiration of the principal agreement, and may still be in the APHT (the Agreement of Assurance) even if the APHT provider dies.

In the future, it is expected that the government through the National Land Agency can organize the process of land certification in a relatively short time, so that it can support the economic activities of the community.

\section{References}

[1] Boedi Harsono 2003 Hukum Agraria Indonesia sejarah Pembentukan Undangundang Pokok Agraria Isi dan Pelaksanaannya Djambatan Jakarta

[2] Habib Adjie 1999 Hak Tanggungan Sebagai Lembaga Hak Jaminan Atas Tanah Mandar Maju Bandung

[3] Irawan Soerodjo 2002 Kepastian Hukum Hak Atas Tanah di Indonesia Arkola Surabaya

[4] M. Bahsan 2007 Hukum Jaminan dan Jaminan Kredit Perbankan Indonesia Raja Grafindo Persada Jakarta

[5] Maria S.W. Sumardjono 2001 Kebijakan Pertanahan antara Regulasi dan Implementasi Buku Kompas Jakarta

[6] Nur Hayatun Nufus 2010 Proses Pembebanan Hak Tanggungan Terhadap Tanah 


\section{JURNAL AKTA}

Yang Belum Bersertipikat (Studi di PT Bank Rakyat Indonesia Tbk Unit Bekasi Kota) Tesis of Diponegoro University Semarang

[7] Purwahid Patrik \& Kashadi 2008 Hukum Jaminan Faculty of Law-Diponegoro University Semarang

[8] Soerjono Soekanto dan Sri Mamudji 2007 Penelitian Hukum Normatif (Suatu Tinjauan Singkat), Raja Grafindo Persada, Jakarta

[9] Undang-undang Nomor 4 Tahun 1996 Tentang Hak Tanggungan Atas Tanah Beserta Benda-Benda Yang Berkaitan Dengan Tanah,

[10]Undang-Undang Nomor 24 Tahun 1997 Tentang Pendaftaran Tanah.

[11]Undang-Undang Nomor 2 Tahun 2014 Tentang Perubahan Atas Undang-Undang Nomor 30 Tahun 2004 Tentang Jabatan Notaris

[12] Peraturan Pemerintah Nomor 37 Tahun 1998 Tentang Peraturan Jabatan Pejabat Pembuat Akta Tanah 